\title{
Analysis of 2017 risk communication on Human Monkey Pox outbreak in Nigeria's News Media
}

\author{
Charity Ben-Enukora ${ }^{1}$, Olusola Oyero ${ }^{2}$, Nelson Okorie ${ }^{3}$, Oscar O. Odiboh ${ }^{4}$, Babatunde K. Adeyeye \\ Department of Mass Communication, Covenant University Ota, Nigeria.
}

Received: March 17, 2020. Revised: July 13, 2020. 2nd Revised: August 22, 2020. Accepted: September 11, 2020. Published: September 22, 2020.

\begin{abstract}
This study quantitatively analyzes the risk communication contents of the human Monkey pox epidemic in 2017 as reported in selected Nigeria's national newspapers (The Guardian, Punch, This day and Vanguard). Framing theory and Issue-attention cycle model formed the theoretical foundation of the study. Data for this study was obtained through the census method. Thus, all the daily editions of the selected newspapers within the study period were searched and reports on the monkey pox epidemic found were contentanalyzed. Findings indicate that monkey pox reports were placed in less prominent positions as straight news within the selected tabloids. Tension and controversy were key reportorial approaches to monkey pox happenstances nationwide. Reports on precautionary measures against the spread of the monkey pox virus were few. However, delayed and lethargic reports of the monkey pox epidemic were found in all the selected tabloids. This study contributes to empirical evidence on the delay in communicating health risk and the unsatisfactory reportage of infectious diseases outbreaks in Nigeria, contrary to global concerns of promoting good health and wellbeing for all. Therefore, as zoonotic diseases such as monkey pox continue to re-emerge all-around the globe, the study recommends that the news media should prioritize infectious diseases prevention as part of their risk communication advocacy to reduce vector interactions with human and nonstop daily updates during public health emergencies through the news media to increase trust in public health officials and the response efficiency.
\end{abstract}

Keywords - Issue-attention cycle, Media coverage, Monkey Pox virus, Public Health Emergency, Risk communication, zoonoses.

\section{INTRODUCTION}

Monkey pox is a rare zoonotic virus transmitted from animals to humans. It is "a pox-like disease first identified in 1958 among colonies of monkeys in Denmark" p.7 [1]. The Human Monkey pox (HMP) was first diagnosed in a 9-year old boy in 1970 in the Democratic Republic of Congo, a central African country formerly known as the Zaire
Republic. A major outbreak of the disease was subsequently reported in the same country between 1996 and 1997 [2]. Since then, endemic cases of HMP have been reported in the rainforest regions of the Congo basin spreading to other African countries including Ivory Coast, Liberia, Sierra Leone, Nigeria, Cameroon, Central African Republic, Gabon and Sudan [2]. However, the first and the largest human Monkey pox epidemic outside the African continent so far was recorded in the United States of America with a total of 47 reported cases in 2003 [3]. It is for this leap and spread that HMP has been circumstantially categorized as a public health endemic requiring emergency action [1].

Unrestricted access to good healthcare reduces emergencies within the framework of the United Nations' Sustainable Development Goal Three (SDG 3). One of the aspirations of the United Nations under the health agenda is eliminating all Neglected Tropical Diseases (NTDs) among other communicable diseases by 2030 , thereby making the world safe from epidemic and pandemic threats [4]. The burden of NTDs such as HMP is generally gruesome in low-income countries with ill-equipped healthcare infrastructure particularly in the absence of an approved vaccine [5].

To cushion this effect, risk communication through the mass media is often employed to sensitize the affected and vulnerable populations about health risks and also persuade them to adopt precautionary behaviors that would reduce the health risks.

Emergency risk communication is the real-time exchange of authentic information to douse fears of epidemics and alleviate public vulnerability. Improving public knowledge and persuading them to adopt protective behaviors that would reduce further transmission of infectious diseases is also within the purview of risk communication. Public health officials recognize the essence and existentiality of emergency risk communication during disease outbreaks. They understand that prevarication during such outbreaks is as dangerous as a frightening disease that spreads like wildfire. Therefore, the World Health Organization (WHO) [6] maintains that "accurate information provided early, often, and in languages and channels that people understand, trust and use, enables individuals to make choices and take actions to protect themselves, their families and communities from threatening health hazards"(p. ix). 
When diseases break out, the mass media readily serve to mass-mobilize public awareness and education, which are expected to translate into mass actions against the emergent diseases.

Although there are sociological, psychological and ecological factors that could shape individuals' knowledge and perception of public health epidemics, the mass media influence collectively outweighs them all [7], [8]. Nationwide sensitization and public enlightenment campaigns in the mass media contributed immensely to the quick responses recorded in various public and private institutions during the Ebola virus crisis in Nigeria [9]. The media, therefore, play a fundamental role in controlling and eliminating epidemics through the recurrent presentation of dispassionate information relating to the disease.

However, media reports of epidemic outbreaks lead to trepidation, angst, and uncertainty especially among the vulnerable, thereby heightening tension in specific cases of vaccine-unpreventable diseases such as HMP. Moreover, the media have been accused of inconsistent and sensational reports diseases outbreak [10]. Inconsistent reports and misleading information are sometimes not entirely attributable to journalists; government officials and nongovernmental organizations also stand accused according to [11]. The media reports to the public based on editorial interpretation of events and preferred frame of discourse. Reportorial frames could color public perception of epidemics positively or negatively and engineer public reactions to risk communication regarding disease outbreak.

Although studies on media coverage of health issues in different regions of the world and Nigeria abound. [12], [13] [14] and [15] carried out some studies on monkey pox, but the dearth in research regarding the attention-cycle and the dimension of risk communication messages during monkey pox outbreaks is not in doubt. This study employed a quantitative research method to analyze the risk communication contents of selected newspapers circulated in Nigeria within the period of the epidemic, focusing on the following objectives:

1. To determine the level of prominence accorded to the human Monkey pox epidemic by the selected newspapers.

2. To establish the risk communication direction of the story frames used in the reportage of the human Monkey pox by the selected newspapers.

3. To ascertain the pattern of attention-cycle for the Monkey pox epidemic reportage in the selected newspapers.

\section{LITERATURE REVIEW}

\section{A. Public Health Emergencies and Risk Communication}

The resurgence of diseases previously considered eradicated in many parts of the world and Africa, in particular, gives cause for concern. It indicates that more epidemiological infections could re-emerge as the human population grows, global travels increase, and entrenched socio-cultural practices remain unchecked. Proactive planning towards the periodic outbreak of diseases would enhance response preparedness, control and the eradication of the diseases as they re-emerge. To boost watchfulness towards disease outbreaks, the International Health Regulations (IHR) (2005) classified various diseases as Public Health Emergency of International Concern (PHEICPHEIC) [16]. Among the listed hemorrhagic diseases requiring attention under this category is the human monkey pox virus, which has become a recurring decimal in Africa.

One of the primary transmitters of monkey pox virus is human contact with the blood and bodily fluids of infected animals. Scratches, bites, and consumption of fairly cooked meat of infected animals also spread the virus. Human-tohuman transmissions arise from close contact with infected persons' secretions, skin bruises; or reuse of contaminated objects used by infected persons. Prolonged face-to-face contacts with household members of active cases trigger a greater risk of infection [2]. An infection could also happen through inoculation or mother-to-child diffusion. Unprotected handling of the dead bodies of infected patients during outbreaks constitutes a hazard as the dead body remains contagious several days after death [1].

Before 2017, monkey pox epidemic cases were recorded in 1971 in Nigeria. In 1978, the country witnessed its resurgence though without any officially recorded death. It came back in 2017. That year, the reappearance of the virus through 97 officially reported cases of the viral infection across the country caused panic and restiveness. In the southeast and south-south regions of the country, rumors of deadly monkey pox vaccine allegedly administered by the Nigerian Military in public primary and secondary schools led to the forceful withdrawal of children against the teachers' resistance. Twenty-four days elapsed before the Nigerian government could obtain laboratory evidence from the WHO Regional Laboratory in Dakar, Senegal to confirm cases discovered in Yenagoa, Bayelsa State [17]. Although no death was recorded during the epidemic, except for a resulting suicide case, confirmed cases spread across 20 states out of the 36 states in Nigeria.

\section{B. Media coverage of public health epidemics}

Public health epidemics tend to generate widespread media attention due to its potential threats to all societies across boundaries. Media coverage of health matters significantly provides surveillance systems on diseases across the globe [18]. Studies on media coverage of health issues concur that mass media reports of epidemics can provoke positive health behaviors and reduce the tendencies of the further spread [19], [20]. However, [21] notes that disparities in media coverage on health matters are the resultant effect of differential perception of public agenda on health issues amongst public information officers and journalists. Thus, the media may not adequately capture emergency risk communication messages as conceptualized by health officials. The implication is the resultant disparity in media reports during the outbreak of epidemics. 
While studies on media coverage of epidemics such as Ebola virus, Lassa fever, Influenza, SARs, Zika virus and other epidemics in diverse regions of the world have been well documented, there is limited independent examination of media coverage of monkey pox epidemic in Nigeria irrespective of sensitization campaigns carried out by the media during the epidemic [22]. The extent of the media reports, the frames used in constructing the messages and the pattern of attention given to the monkey pox reports have not received adequate attention in literature. This gap in the literature is what this study aims to fill.

\section{Theoretical Framework}

Framing theory and Issue-Attention model form the theoretical framework of this study. Framing theory deals with how a message source constructs, organizes and presents ideas in communication channels, which in turn help recipients' interpretation and understanding (of the message). Reference [23] believes that individuals are incapable to cognize the world fully, so they employ interpretative appurtenances to classify information and interpret messages meaningfully. Thus, the frames result in a meaningful interpretation of media messages as the patterns of presentation of essentially identical decision-making scenarios influence people's choices and evaluation of the various options presented to them. According to [24], the construction of media messages in specific frames tends to lend different meanings to similar messages. Subtle changes in the choice of words and the description of an event increase or decrease the salience of such issues and the audience's perception of the situation. In other words, the mode of presentation of the Monkey pox reports would affect public perception and interpretation of the epidemic as well as the public response to the epidemic.

Unlike the Framing theory which is mediated, Anthony Down's Issue-attention cycle model [25] describes the systematic rise and fall of the salience of an issue. Downs states that subject matters suddenly leap into prominence, linger for a short time, and then (though still largely unresolved) gradually fades from the centre of public attention as they are replaced by more trending issues, thereby moving into their "crisis" phases. Each issue of 'crisis' undergoes five sequences of attention. The first is the preproblem stage (the existence of a highly undesirable social condition, which experts may already be aware of but not yet in the realm of public attention). Second is the alarmed discovery and euphoric enthusiasm (sudden public awareness of a particular problem accompanied with anxiety about the possibility of resolving the problem in a short time). Third is realizing the cost of significant progress (the consciousness of the high cost of finding solution to a certain issue, both in financial terms and substantial human and material sacrifices). Fourth is the gradual weakening of intense public attention (public attention toward this particular issue wanes as a new issue enters the 2nd stage consequently claiming greater public attention). The fifth and last phase is the postproblem stage where the problem is solved and therefore undeserving of public attention [26].
Issue-attention cycle stems from the nature of certain subject matters and in the way major communication media interact with the public [25]. Thus, this study provides insight into the trend of media attention on Monkey pox epidemic in Nigeria.

\section{MATERIALS AND METHOD}

This study adopted a quantitative analysis. Contents of selected national newspapers (This day, The Guardian, Punch, and Vanguard) on the 2017 Monkey pox epidemic in Nigeria were arranged according to key themes and thereafter analyzed. Selection of the tabloids was based on nation-wide circulation, diversity of readership penetration and specialized health beats which guaranteed that the Monkey pox reports were found in them [27], [28].

Contents studied were direct and indirect articles on Monkey pox published between September 22 (when the index case of Monkey pox was reported) and November 30, 2017. Thus, all materials for the study were limited to this period. Seventyone (71) editions of the four (4) newspapers were found on the newsstands within the study period. Therefore, the total population for the study was 284 (70 editions $\mathrm{x}$ 4) publications. The census method was applied for the content analysis. Thus, all editions of the four selected newspapers within the period of study were carefully examined to identify every article on Monkey pox and all related articles. The search yielded a total of 145 reports $(51 \%$ of the total population) that appeared in the selected newspapers (Vanguard 40, Punch 44, The Guardian 35 and This day, 26) which was used for the analysis.

\section{RESULTS}

The following are the outcomes of the analysis based on prominence, content categories, story frames and attention cycle of newspapers' reports on Monkey pox.

\section{The prominence accorded to the 2017 human Monkey pox epidemic by the selected newspapers}

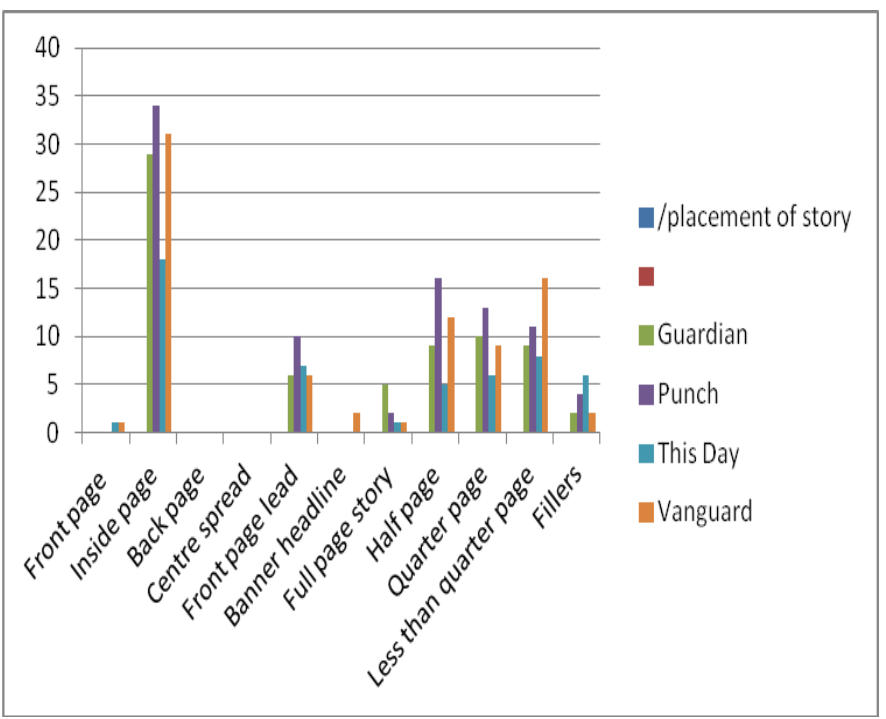


Fig. 1: Placement of the human Monkey pox epidemic reports

Fig. 1 illustrates that the Monkey pox epidemic was not offered prominent placement in the selected newspapers as very few stories were placed on the front pages and no story appeared on the centre-spreads and the back pages of the newspapers. Although, front-page leads were employed to a large extent, only Vanguard newspaper used banner headlines for the story. Also, only a few stories occupied full pages in the newspapers.

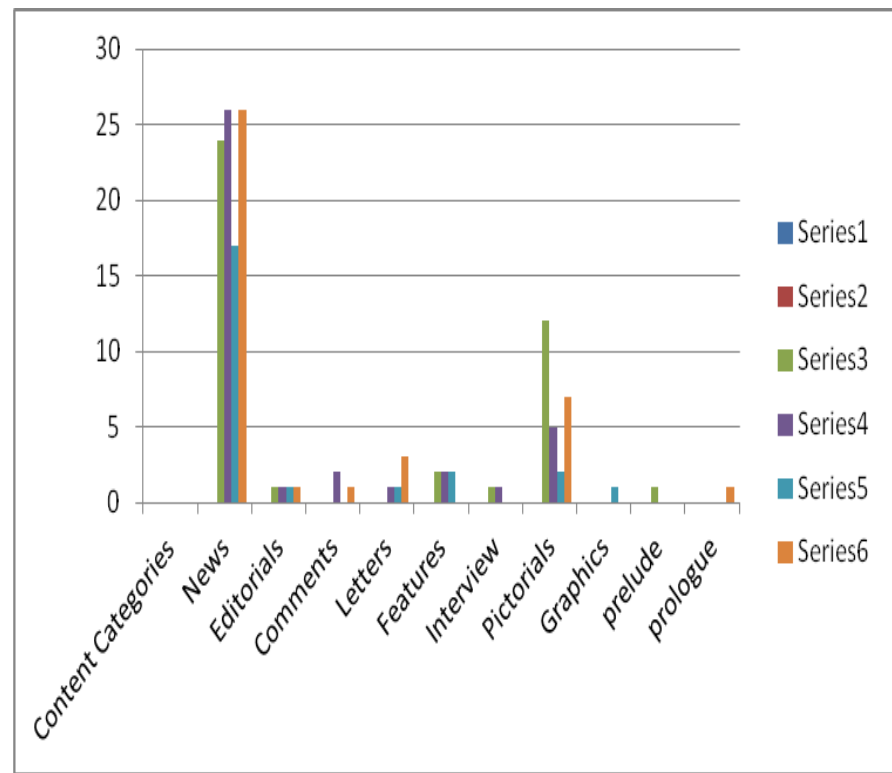

Fig. 2: Content categories of the monkey pox reportage in the selected newspapers

Fig. 2 delineates the content categories of the monkey pox reports. The data show that the majority of the risk communication contents appeared as news stories. Also, pictorials were widely used by the selected tabloids in telling the stories of the epidemic particularly the reports about the pandemonium. The figure also indicates that content categories such as comments and interviews were the least captured in the reports.

\section{The direction of the story frames adopted in the reportage of the human Monkey pox by the selected newspapers}

The major headlines and sub-heads were used as benchmarks to determine the dominant frames used for the monkey pox reportage in the selected newspaper.

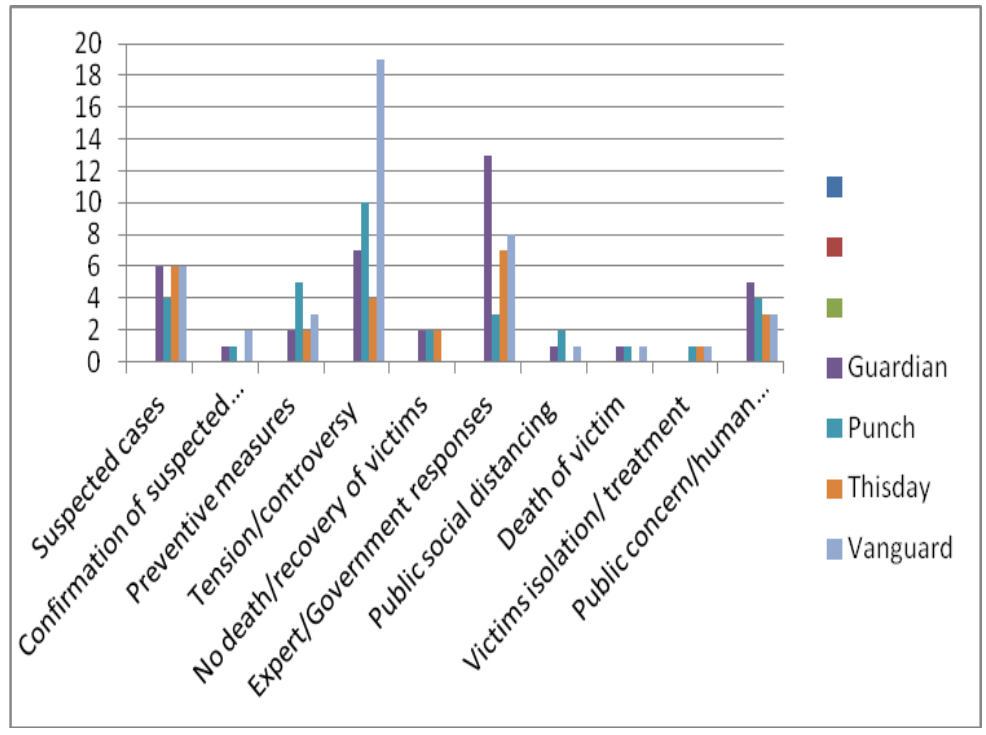

Fig. 3: Story frames for Monkey Pox reports

The story frames depicted in fig. 3 shows the controversy that surrounded the Monkey pox epidemic dominated the reports in the selected newspapers. The claim that the outbreak was triggered by the delivery of free medical treatment by the Nigerian Military in partnership with the Federal Government and the rumor about a certain student that died after being vaccinated caused pandemonium in different states which were captured in the newspapers' reports. Consequently, story frames on government responses to the allegations followed suit before the frame of suspected and confirmed cases. However, the reports on public social distancing practices and preventive measures for the control and elimination of the disease were insufficient.

3. Pattern of attention cycle for the Monkey pox epidemic reportage in the selected newspapers.

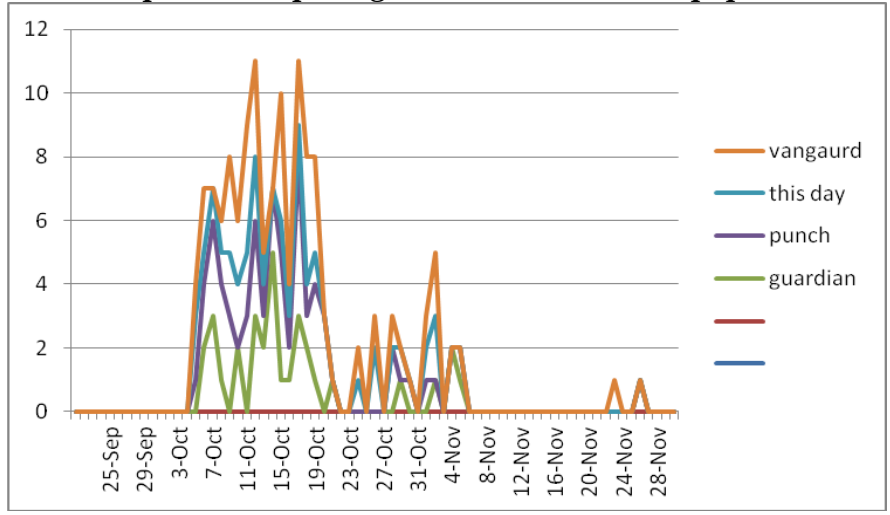

Fig. 4: Illustration of the attention cycle of the Monkey pox epidemic reportage.

Fig. 4 represents the pattern of reportage demonstrated by the selected newspapers during the Monkey pox epidemic. Irrespective of the NCDC record of the epidemic on September 22, 2017, there was no media report on the issue until October 5 when the news suddenly appeared on the 
pages of the selected newspapers. Thus, news reports on the monkey pox epidemic appeared 14 days after the index case was identified. The reports reached its peak between October 11 and 18 and suddenly fluctuated between October 19 and November 5, before its disappearance from the pages of the selected newspapers for more than a month (from October 6 to November 21). Then reappeared with few stories from November 22 to 25 but disappeared finally afterwards.

\section{DISCUSSION OF FINDINGS}

This study has established that the reports of the Monkey pox epidemic did not occupy prominent positions in the selected newspapers. The result corroborates the finding of previous studies which established that the media do not offer prominent placement to reports on health issues including stories on outbreak epidemics in Nigeria. For instance, [29] affirmed that the media played a great role in curbing the spread of the virus in Nigeria through the frequency of the reportage, though Nigerian newspapers did not attach much prominence to the coverage of the epidemic. This issue is not peculiar to daily tabloids as [30] found that the reports of the meningitis outbreak in online newspapers were also not prominently displayed.

Moreover, irrespective of the fact that a considerable number of front-page leads were used, readers may be reluctant to trace the pages where the stories are located to read them. Even when they attempt to do that, other stories could capture their interests causing them to overlook the initial story they were searching for. The implication is that readership of the Monkey pox reports could be low.

The study also found that the monkey pox news generated panic which resulted in pandemonium and controversy. Consequently, the reports on monkey pox vaccine scare, the pandemonium and forceful withdrawal of children from schools particularly in the south-south and southeastern part of Nigeria, as well as allegations about the Nigerian military using the alleged Monkey pox vaccine as a chemical weapon against the Southeast region and Military denial of the allegations dominated news reports in the selected newspapers. Thus, newspapers became preoccupied with the control of rumor and panic generated by the news of the Monkey pox outbreak, followed by reports on the identification of new cases and government emergency responses. The study findings on widespread panic reported by the tabloids corroborate the previous claims that the news of contagious diseases outbreaks also arouse public anxiety and unrest in other countries around the globe [30], [31], [32]

Whereas few reports focused on preventive measures that will reduce chances of infection and further spread of the disease. This result confirms [31] assertion that significant events such as newly identified cases and governmental actions increased news coverage of public health epidemics. Additionally, the finding proves that the controversy generated by a public health epidemic could also increase the volume of news stories on the epidemic.

However, risk communication dimensions regarding the preventive measures that would reduce further spread of the disease were very limited. This finding contradicts previous studies that observed that there was widespread media campaign geared towards the prevention of the Ebola epidemic and a significant majority of Nigerians adopted anti-Ebola health practices as a result of the media campaign [32], [33]. It could, therefore, be argued that the poor coverage of the preventive measures of the Monkey pox epidemic stems from the fact that the disease is not as deadly as the Ebola virus. Nevertheless, the implication of low reportage of preventive measures is limited information on personal hygiene and social distancing practices which would reduce the chances of infection among the vulnerable population. Inadequate information could bring about harmful behaviors that may jeopardize the public health responses. Little wonder [34] maintain that the central goal of media reports on the outbreak of diseases should be to promote messages on prevention of new infections through a change in the pattern of behaviors among the people.

The pattern of the Monkey pox reportage displayed in fig. 4 confirms that Downs' Issue-attention Cycle Model also applies to the reportage of public health epidemics. The finding also confirms [35] assertion that the media do not report diseases outbreak immediately. The government through the disease control agencies has the primary responsibility of announcing disease outbreak to the press before such information appears in the media. The delay in media reportage of outbreak of epidemics has been attributed to the governments, especially in West Africa (including Nigeria) unwillingness to rapidly report the outbreak of epidemics and sometimes under-report the scale of the outbreaks [36]. The authors identified weak health system capacity, fear of international isolation/stigmatization, poor prioritization of health and health emergencies, weak leadership and accountability, as well as knowledge deficit on outbreaks and management approaches as some of the reasons for government's delay in revealing the occurrence of epidemics to the media.

More importantly, previous studies have suggested that diseases run their normal course when there are no media reports [37]. Besides, delay in media coverage contributes to increase in cases of the infection during infectious diseases outbreaks [38]. Hence, the untimely announcement of public health epidemic such as Monkey pox through the news media could have a devastating effect as public trust can be effectively established if the emergent disease is brought to public notice early enough [39], [40]. Therefore, the delay in the reportage of the Monkey pox disease outbreak for almost two weeks may have contributed to the subsequent increase in the number of suspected and confirmed cases recorded during the period.

We also found that attention on the Monkey pox epidemic fluctuated over the period. The story suddenly appeared and peaked with media attention between October 9th and $18^{\text {th }}$ 2017; but suddenly declined as new issues such as Anambra state gubernatorial elections and other stories emerged and 
eventually disappeared with inconclusive report on whether the epidemic has been contained or not leaving a vacuum in the Monkey pox coverage. Similarly, [40] observed that "news coverage gets diluted, and the signal triggered by mass reporting at the onset of an epidemic fades away after some time". Sudden decline in risk communication or outright diversion of attention to other issues during diseases outbreak could bring about public uncertainty regarding the control and total elimination of the epidemic. More so, it could be bring about distrust on the public health system and irrational actions from the public that can escalate the curve of diseases' spread which may be difficult to manage.

Remarkably, the media have been accused of being reluctant to report epidemics especially when the victims or suspected cases are few. Media attention on the SARS outbreak was found to become intense when hundreds of readers were evacuated at the Hong Kong Central Library because of a suspected SARS case among its staff which automatically increased the number of SARS contacts [41]. It could be argued that the volume of risk communication contents on Monkey pox was associated with the number of victims affected. However, media coverage of other hemorrhagic diseases such as Lassa fever which have continued to record large number of confirmed cases and case fatality rates was limited in content and undermined by the time of the day the broadcasts are made [42], also the news media did not offer prominent placement to Lassa fever reports [43].

\section{CONCLUSION AND RECOMMENDATIONS}

The findings of this study contribute to empirical evidence on inadequate reportorial countenance of the news media on infectious diseases outbreaks in Nigeria and in the West African region. This study found that the 2017 Monkey pox occurrence (which was termed the largest Monkey pox outbreak) in Nigeria was not matched with adequate risk communication messages in the news media. The selected Nigerian newspapers did not offer prominent positions to the public health epidemic. The national dailies constructed the majority of the news stories using the tension/controversy that erupted with the alleged Monkey pox vaccine and the institutional actions for emergency management of the disease as the predominant frames while messages on Monkey pox preventive measures were inadequate. This study also found that there was delay in risk communication through the news media. Lastly, attention on risk communication during the Monkey pox outbreak dwindled as new issues emerged. These findings contribute to empirical evidence on delay in communicating health risk to the public and the unsatisfactory reportage of infectious diseases outbreaks in Nigeria, contrary to global concerns of promoting good health and wellbeing for all. Based on these findings, the following are recommended for an improved approach to risk communication during future disease outbreaks in Nigeria:
- Reports of public health epidemics should be given prominent positions particularly on front pages of newspapers rather than the use of front-page lead only.

- As zoonotic diseases continue to re-emerge, the news media should prioritize infectious diseases prevention as part of their risk communication advocacy to reduce vector interaction with human.

- Disease control agencies should endeavor to offer immediate announcement disease outbreak to media organizations for onward information to the general public to keep the populace on alert.

- Risk communication through the news media during contagious disease outbreaks should involve continuous daily updates of the responses in order to increase trust in public health officials and the response efficiency.

- Lastly, media reports of public health epidemics should be conclusive so that the public will not be left in doubt on whether disease outbreak has been contained or not.

\section{REFERENCES}

[1] World Health Organisation, "Weekly bulletin on outbreaks and other emergencies", 2017. Available: http://www.afro.who.int/healthtopics/disease-outbreaks/outbreaks-and-other-emergencies-updates

[2] The Conversation, There are reports that Monkey pox has resurfaced in Nigeria. What you need to know, 2017, October 12. Available: http://theconversation.com/monkey pox-has-resurfaced-in-nigeriawhat-you-need-to-know-85532

[3] N. Sklenovská and M. Van Ranst, "Emergence of Monkeypox as the Most Important Orthopoxvirus Infection in Humans" Frontiers in public health, vol. 6 (241), 2018. https://doi.org/10.3389/fpubh.2018.00241

[4] United Nations, "Sixty-ninth session of the United National General Assembly: Draft outcome document of the United Nations summit for the adoption of the post-2015 development agenda". New York: United Nations;

2013 http://www.un.org/ga/search/view_doc.asp?symbol=A/69/L.85\&Lang= E

[5] O. Odiboh, O. Omojola, N. Okorie and T. Ekanem, "Sobotone, Ponkiriyon, Herbal Marketing Communication, and Nigeria's Healthcare System",. Presented at the $4^{\text {th }}$ International Conference on Education, Social Sciences and Humanities, SOCIOINT $10^{\text {th }}-12$ th July 2017, Dubai, United Arab Emirate.

[6] World Health Organization, "Communicating risk in public health emergencies. Geneva", $2018 . \quad$ Available: http://www.who.int/riskcommunication/guidance/download/en/

[7] C. Ben-Enukora, L. Amodu, and N. Okorie, "Health Communication and Hepatitis Health Management: A Study on the Awareness and Behavioural Practices in Nigeria", Journal of Health Management, vol. 21 (2), 2019, pp. 313-325

[8] C. A Ben-Enukora, Oyero, N. Okorie, and E. Adesina, "Risk communication and Lassa fever management in Nigeria: Engaging new communication technologies for message delivery". Paper presented at the $34^{\text {th }}$ IBIMA Conference, 2019, pp. 7384-7392.

[9] Sustainable Conversations, The odds of Nigeria's Health System: A call for Health Communication, 2017, October 20. Available: https://sustainableconvos.com/the-odds-of-nigerias-health-system-acall-for-health-communication/

[10] D. J. Dausey, K. A. Ricci, M. A Stoto, E. M., Sloss, L. M Davis, N. Lurie, S. S. Myers, S.S., Olmsted, M. S., Ridgely, and J. Wasserman, "Communication with the Public in outbreaks of West Nile Virus, SARS, Monkey pox and Hepatitis A in the United States", 2005. Available:Public_Health_Assessment_in_Outbreaks_of_West_Nile $\% 2$ $0(1)$.pdf 
[11] O. Odiboh, O., Omojola, T., Ekanem, and T. Oresanya, "NonGovernmental Organisations in the Eyes of Newspapers in Nigeria: 2013 - 2016 in View", Covenant Journal of Communication (CJOC), 2017, pp. ....

[12] L. E. Odoemelam, F. N. Onumadu, and I. V. Arua, "Media Coverage Of Hiv/Aids: A Content Analysis Of Two Nigerian Newspapers (The Guardian And Daily Sun", International Journal of Scientific \& Technology Research, vol. 3, 5, pp. 190-193, 2014.

[13] E. D. Akpor, and A. Clever, "Media coverage of ebola virus disease in nigeria using guardian and punch newspapers". International Journal of International Relations, Media and Mass Communication Studies, vol. 2, (2), pp. 41-50, 2016.

[14] O. B. Okanume, The Monkey pox virus and the inherent danger in rumour-mongering: Focus on Nigeria print media reportage of the crisis. New Media and Mass Communication, vol. 64, , pp. 54-64, 2017.

[15] J. O, Wogu, C. O., Chukwu, E. S., Orekyeh, C. O. Nwankiti, and S. Okoye-Ugwu, "Assessment of media reportage of monkeypox in southern Nigeria" Medicine, 99, 5(e17985), 2020.

[16] World Health Organisation, "Mapping the risk and distribution of epidemics in the WHO African Region: A Technical Report" 2016, pp. $1-62$.

[17] S. Ogundipe, and C. Obinna, (Vanguard, 2017, December 19), After containing Ebola, Nigeria not prepared for disease epidemics, Available: https://www.vanguardngr.com/2017/12/containing-ebolanigeria-not-prepared-disease-epidemics/

[18] E. Mykhalovskiy and L. Weir, "The Global Public Health Intelligence Network and early warning outbreak detection: A Canadian contribution to global public health", Canadian Journal of Public Health, vol. 97 (1), pp. 42-44, 2006.

[19] M. Majumder, S., Kluberg, M., Santillana, S., Mekaru, S. \& J. S. Brownstein, "Ebola outbreak: Media events track changes in observed reproductive numbers", PLoS Current outbreak, 2014. Available: http://currents.plos.org/outbreaks/article/2014-ebola-outbreak-mediaevents-track-changes-in-observed-reproductive-number/

[20] S. Collinson, K. Khan, and J. M. Heffernan, "The effects of media reports on disease spread and important public health measurements", 2015. Available: https://doi.org/10.1371/journal.pone.0141423

[21] J. M. White, "Potential barriers to mass media coverage of health issues: Differences between public information officers and journalists regarding beliefs central to professional behaviours". Journal of Public Relations Research, vol. 25, pp. 123-140, 2013.

[22] S. Oyadongha, D. Udoma and E. Ayungbe, (Vanguard, 2017, October 9), Fear grips A/Ibom as Monkeypox hits Uyo. Available: https://www.vanguardngr.com/2017/10/fear-grips-aibom-residentsmonkey-pox-hits-uyo/

[23] E. Goffman, Frame analysis: An essay on the organization of experience, Harvard University Press, 1974.

[24] Y. Auerbach, and Y. Bloch-Elkon, "Media framing and foreign policy: The Elite P vis-à-vis US policy in Bosnia, 1992-95”, Journal of Peace Research, 42(1), 83-99, 2005.

[25] A. Downs, "Up and down with ecology - the 'issue-attention cycle'. Public Interest, 28, pp. 38-50, 1972

[26] M. Dyussenov, "The issue-attention cycle model and corruption issues in Canada and Kazakhstan". Public Policy and Administration, 15(2), 264-278, 2016.

[27] D. Jowitt, G. Danaan, and T. Obateru, Understanding the newspaper business in Nigeria. Cabridge: Cambridge Scholars Publishing, 2016.

[28] A. Agboke, (2019, May 28) 10 leading Nigerian newspapers, Hintnaija,. Available: https://hintng.com/10-leading-newspapers-inNigeria/

[29] K. Bello-Osagie, (The Nation, 2015, January 8), Ebola: Study lauds, faults media role, Available: http://thenationonlineng.net/ebola-studylauds-faults-media-role/

[30] M. S. Smith and G. M. Tietaah, "Online Media Surveillance: Coverage of Meningitis Outbreaks in Ghan", Athens Journal of Health , Vol. 4, 4, pp. 303-320, 2017.

[31] M. D'Agostino, F. Mejía, I. Brooks, M. Marti, D. Novillo-Ortiz and G. de Cosio, "Fear on the networks: Analyzing the 2014 Ebola outbreak", The Revista Panamericana de Salud Pública, vol. 41, p.e134, 2017. Doi: 10.26633/RPSP.2017.134
[32] D. Roy, S. Tripathy, S. K. Kar, N. Sharma, S.K. Verma and V. Kaushal, "Study of knowledge, attitude, anxiety \& perceived mental healthcare need in Indian population during COVID-19 pandemic", Asian journal of psychiatry, vol. 51, p.102083, 2020. https://doi.org/10.1016/j.ajp.2020.102083

[33] J. Qiu, B. Shen, M. Zhao, Z. Wang, B. Xie and Y. Xie, "A nationwide survey of psychological distress among Chinese people in the COVID19 epidemic: implications and policy recommendations", General Psychiatry, vol.33(2), p.e100213. doi: 10.1136/gpsych-2020-100213

[34] S. Tsung-Jen, W. Rosalyna, and B. Dominique, "Media coverage of public health epidemics: Linking framing and issue attention cycle toward an integrated theory of print news coverage of epidemics. Mass Communication and Society, 11(2), 141-160, 2008.

[35] A. O. Asaolu, G. Ifijeh, J. Iwu-James, and O. Osayande, "Newspaper Coverage of Ebola Virus Disease Epidemic in Nigeria: Implications for Prevention and Control", International Journal of Communication and Health, vol. 10, pp. 53-58, 2016

[36] N. Okorie, and B. J. Namtira, "Measuring Media Campaigns Effectiveness for Environmental Health for Sustainable Development: A Study of Ebola Outbreak in Lagos State, Nigeria", Journal of Health Management, vol. 19 (4), pp. 553-562, 2017.

[37] O. Oyero, and A. Salawu, "Where Lies the Answer? HIV/AIDS prevention campaign and the rising prevalence in South Africa", Mediterranean Journal of Social Sciences, vol. 5(23), pp.2026-2034, 2014.

[38] D. Li, Y. Wu, P. Wen, and W. Liu, "The qualitative analysis of the impact of media delay on the control of the infectious disease", 2016. Available: https://arxiv.org/ftp/arxiv/papers/1609/1609.03925.pdf

[39] S. A. Omoleke, O. Ajibola, J. O. Ajiboye, and R. O. Raji, "A quagmire of epidemic disease outbreaks reporting in Nigeria", BMJ Global Health Journal, vol. 3 (1), 2017. Available: http://dx.doi.org/10.1136/bmjgh-2017-000659

[40] J. M. Tchuenche, and C. T. Bauch, "Dynamics of an Infectious Disease Where Media Coverage Influences Transmission", ISRN Biomathematics, $2012 . \quad$ Available: http://dx.doi.org/10.5402/2012/581274

[41] O. B. Achieng, O. G Lawi,. and K. J. Nthiiri, "Modelling the impact of delay in media coverage on the dynamics of Ebola in a logistically growing population", International Journal of Pure and Applied Mathematics, vol. 110 (1), Pp. 125-141, 2016.

[42] J. O. Wogu, C. O. Chukwu, K. A. Nwafor, E. A., Anikpe, J. C. Ugwuoke, C C. Ugwulor-Onyinyechi and C. Eseadi, "Mass media reportage of Lassa fever in Nigeria: A viewpoint", Journal of International Medical Research, vol. 48(1) pp.1-7, 2019.

[43] F.O. Talabi "Coverage of Lassa fever in four Nigerian newspapers", Babcock Journal of Mass Communication. Abstract. Retrieved from https://babcockjmc.com/coverage-of-lassa-fever-in-four-nigeriannewspapers-by-felix-olajide-talabi-ph-d/

[44] C. A. Ben-Enukora, O. Oyero, N. Okorie, and E. Adesina, "Risk communication and Lassa fever management in Nigeria: Engaging new communication technologies for message delivery", in Proceedings of $34^{\text {th }}$ IBIMA Conference, Milan Spain, 2019, pp. 7384-7392.

[45] E. Adesina, O. Oyero, N. Okorie, and C. A. Ben-Enukora, "Risk Communication for Viral Hepatitis Management among Migrants" in Handbook of Research on the Global Impact of Media on Migration, N. Okorie, B. R. Ojebuyi and J. W. Macharia, Ed. IGI Global, 2019, pp 235-252.

[46] B. Adeyeye, L. Amodu, O. Odiboh, O. Omojola, E. Adesina, C. A. Ben-Enukora, "A SWOT Analysis of Indigenous Language Use in Agricultural Radio Programming in Nigeria", in Emerging Trends in Indigenous Language Media, Communication, Gender, and Health, $K$. O. Oyesomi, and A. Salawu Ed., IGI Global, 2020, pp.188-209.

\section{Creative Commons Attribution License 4.0 (Attribution 4.0 International, CC BY 4.0)}

\author{
This article is published under the terms of the Creative \\ Commons Attribution License 4.0 \\ https://creativecommons.org/licenses/by/4.0/deed.en_US
}

